\title{
The Panglima Laot of Aceh: a case study in large-scale community-based marine management after the 2004 Indian Ocean tsunami
}

\author{
CRISPEN WiLSON and MatThew Linkie
}

\begin{abstract}
Despite dating back over 400 years the relevance of traditional fisheries management in Aceh, Indonesia, still remains high. Aceh was, however, greatly affected by the December 2004 Indian Ocean tsunami that claimed an estimated 167,000 lives, including 14,000 fishermen and 59 of the 193 traditional marine leaders (Panglima Laot). This tragic loss of life was accompanied by a substantial loss of local knowledge, such as the locations of hazardous fishing grounds. In this study we describe an innovative project that sought to rebuild a post-tsunami fisheries sector by reengaging and empowering the Panglima Laot. During April-June 2008 GPS (global positioning system) sounding devices were installed on 53 local fishing boats and hazardous fishing areas mapped based on local knowledge, and shared amongst fishermen. During July-December 2008 nearly five million GPS data points were collected, from which detailed bathymetric maps were produced and shared between fishermen and Aceh government officials. Significant project outputs included a map of fishing areas over $20,000 \mathrm{~km}^{2}$, which included three new seamounts, one of which expanded Aceh's provincial boundary by $>1.3$ million ha, and a Panglima Laot decree that reduced fishing in hazardous areas of high coral density by $23.3 \%$. Our findings have wide applicability. Locally, the introduction of GPS technology and sharing of traditional knowledge resulted in fishermen developing and implementing their own management strategies and demonstrating their ability to stay out of restricted areas. Provincially, this project provided a framework through which government agencies and academic institutions could effectively engage with local customary leaders and their fishing communities.
\end{abstract}

Keywords Aceh, coral reef, customary marine tenure, fishing, GPS, Indian Ocean tsunami, Indonesia, local knowledge

\section{Introduction}

Coastal communities across the Indo-Pacific region have a long history of implementing area- and time-based

\footnotetext{
CRISPEN WILSON (Corresponding author) Sumatra Konservasi Alam (Sumatra Nature Conservation), Pulau Weh, Aceh, Indonesia. E-mail conservation@ gmail.com

MATTHEW LinkIE Fauna \& Flora International, Cambridge, UK

Received 19 November 2011. Revision requested 10 January 2012

Accepted 14 February 2012
}

restrictions so they may better manage their marine resources (Ruddle \& Johannes, 1985, 1990; Cinner et al., 2005). In many instances these social processes have evolved over centuries and are an integral part of customs and traditions. There is increasing recognition, especially amongst non-governmental organizations, donors and government, of the value of these customary management systems in delivering improved conservation outcomes (Clifton, 2009; Govan, 2009).

Within the Indonesian province of Aceh the institution of the Panglima Laot dates back as far as the 17th century (Nurasa et al., 1987). The term Panglima Laot is both the name of the institution and the title of the elder fishermen who are elected from among the senior boat captains to lead the fishermen in the immediate area. The duties of the Panglima Laot include enforcing traditional fishing regulations, controlling access to key areas, resolving disputes between fishermen and organizing sea rescues for vessels in distress. Unfortunately, Aceh is better known for the 26 December 2004 Indian Ocean tsunami that claimed an estimated 167,000 lives.

One consequence of so many lives lost in the Indian Ocean tsunami was that much of the traditional knowledge normally handed down from father to son was lost. This loss of local knowledge posed a significant risk for those fishing communities who were trying to rebuild their livelihoods in the aftermath of the tsunami. For example, in the case of purse-seine fishermen who were unfamiliar with the direction of the ocean currents and the locations of underwater hazards, there was an increased likelihood of accidentally damaging their nets on underwater obstructions such as coral reefs. According to boat owners and net vendors the size of a purse-seine net typically used in Aceh after the tsunami is c. 1,200 $\mathrm{m}$ long by $80 \mathrm{~m}$ deep and, if new, costs C. USD 20,000. Besides lost income associated with being unable to go to sea while the net is being repaired, other individuals, such as fish traders, handlers and packers, would also be affected by any temporary reduction in fishing capacity. The fishermen's strong desire to avoid damaging their nets on coral reefs therefore presents an opportunity simultaneously to deliver local livelihood benefits and achieve biodiversity conservation gains.

Throughout Aceh there are currently 193 Panglima Laot. This study focuses on the post-tsunami Community-Based Bathymetric Survey Project (Arie \& Syahbudin, 2009), which worked with 134 Panglima Laot to create partnerships between fishermen and local authorities and build the 
capacity of these local leaders to participate actively in provincial fisheries management. Here, we report on a project component that aimed to engage local fisherman by empowering their customary marine association (Dewan Panglima Laot) to collect the spatial data needed to improve and chart the local knowledge of hazards to fishing gear operation, such as seamounts and deep reefs, and manage fishing resources in the region.

\section{Methods}

\section{Establishing the community-based mapping system}

The Community-Based Bathymetric Survey Project was launched in April 2008 with funding from the Asian Development Bank. This project established eight strategically placed coastal livelihood service centres (in Banda Aceh, Lhoksuemawe, Calang, Lhoong, Meulaboh, Sigli, Meurdeu and Peudada) that gave wide coverage along Aceh's coastline. Each centre was equipped with a longrange single side band radio, marine radio and computer network with internet access. The purpose of these centres was to facilitate the development of a professional, provincewide Panglima Laot network. In addition, there were a series of sub-projects that were designed to improve the livelihoods of fishermen, improve access to markets and improve safety at sea; one of these aimed to engage the fishermen in mapping their marine and coastal waters. Fishermen from three of these centres (Banda Aceh, Calang and Lhoksuemawe) participated in the GPS (global positioning system) mapping portion of the study.

During May-June 2008 sounders with integrated GPS units were installed on 53 local fishing boats used for purse seine $(n=35)$, handline $(n=9)$, long-line $(n=8)$ and gillnetting $(\mathrm{n}=1)$. These boats ranged in length $(8-25 \mathrm{~m})$ and weight (2-43 gross $t$ ). Installing the transducer on purseseine boats involved offloading the net, mooring the boat on the beach during high tide, waiting for low tide and then quickly installing the units when the water was at its lowest.

In exchange for training on traditional navigation and GPS/sounder operation each of the boat captains agreed to allow project staff to board and routinely download the GPS data. In addition the boat captains agreed to provide catch data (volume and species) to the project staff. An important aspect of the project was that the units were given to the three participating Panglima Laot (Banda Aceh, Calang, Lhoksuemawe), and it was their responsibility to decide which boats and captains in their respective areas would participate in the project. Boat captains and boat owners agreed that if they did not share GPS, catch or fishing data or if the boat did not go to sea for 2 months, the Panglima Laot could take back the unit and reassign it to another fisherman.
The GPS/sounders were configured automatically to record longitude, latitude, water temperature and depth every time the boat moved a set number of metres. As the units had a storage capacity of 10,000 points, boats that returned within 24 hours had a sampling distance set to $30 \mathrm{~m}$ intervals. For those boats that travelled longer distances, a sampling interval of $100 \mathrm{~m}$ was set so that the entire trip could be recorded.

\section{Mapping hazardous areas and seamounts}

Data on the location of fishing and hazardous areas were first collected through consolidating local knowledge in focus group discussions. It was anticipated that the fishermen would initially be reluctant to share information about their favourite fishing sites. Therefore, in the beginning, the fishermen were only asked to identify on a map where they had previously damaged their nets. According to Panglima Laot regulations, fishermen are required to come to the rescue of other boats in distress and so it was agreed that it was in everyone's interest to share their knowledge of hazardous locations.

The GPS data collected by the fishermen were used to identify fisheries resources that were well-known to the fishermen but unknown to the scientific community. This included locations of seamounts, large undersea crevices and coral reefs, all representing potentially valuable marine resources both in terms of species diversity and abundance.

\section{Charting ocean currents}

As one of the immediate goals of the project was to help fishermen avoid ripping their nets on underwater obstructions (especially coral reefs), it was important to characterize the ocean currents that would affect the drift of a boat and its net. To achieve this the fishermen wanted to know whether currents in an area consistently flow in a particular direction or are subject to change according to the tides. This was accomplished by quantifying the direction and distance that their nets moved during fishing activity. The typical pattern of a day-fishing boat deploying its net and retrieving the catch can be divided into four main stages (Fig. 1).

\section{Data management and analysis}

Data were downloaded from the fishermen's GPS/sounders using Mapsource v. 6.13.9 (Garmin, Lenexa, USA) and imported into a database. Spatial analysis of the data was performed using ArcGis v. 9.3 (ESRI, Redlands, USA). Three dimensional surface models were created using Surfer $v .8$ (RockWare, Golden, USA) to depict large undersea features (e.g. seamounts and undersea canyons). 


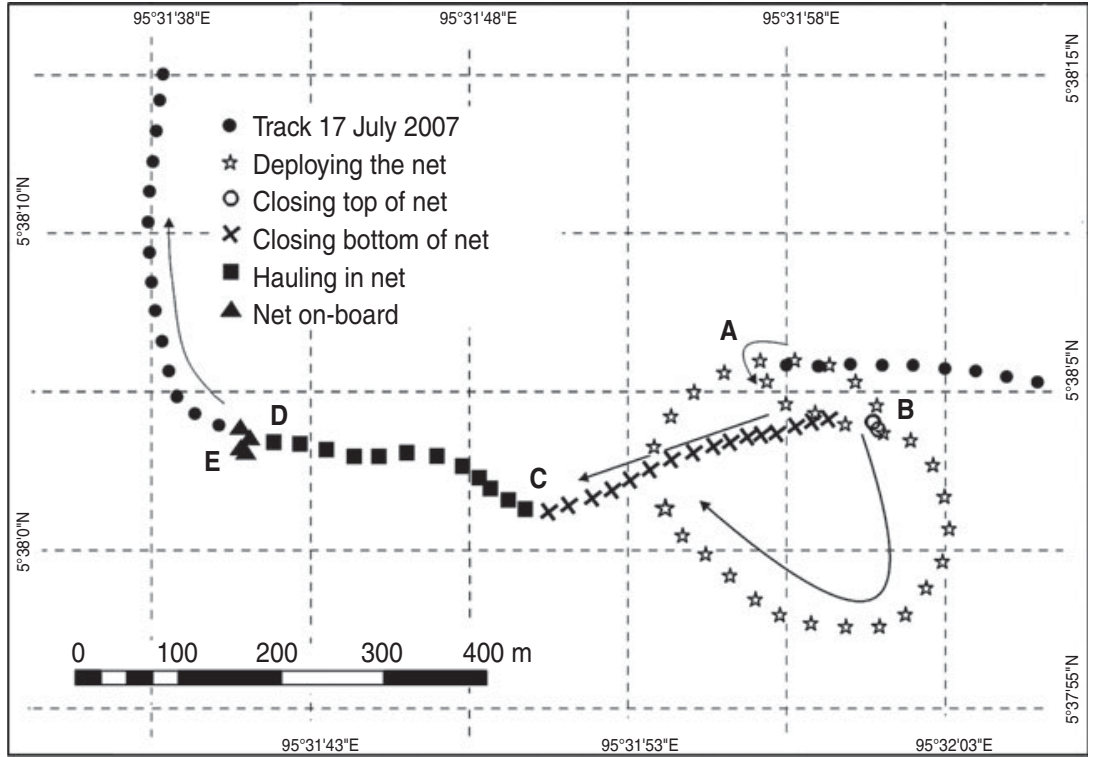

FIg. 1 Typical pattern of an artisanal purseseine boat deploying its net. The first stage (in black dots), is where the boat has approached the school of fish and positioned itself to deploy the net. The second stage is where the boat has quickly deployed the net and is beginning to encircle the school (from point A to B, stars); the third stage (from $B$ to $C$, crosses) is where the bottom of the purse seine is being drawn shut. The fourth stage (from C to $\mathrm{D}$, filled squares) is where the crew is slowly pulling the net on-board. Finally, the boat is repositioned (triangles) to assist in the final stage of hauling the net on-board.

\section{Results}

During July-December 2008 the 53 participating boats contributed 4,967,193 GPS depth readings. All boats originally identified by the Panglima Laot participated. One boat was sold during the project but the new owner and captain agreed to continue participating. There was complete adherence to the agreed terms that the captains receiving GPS units routinely provide data to the Panglima Laot.

\section{Mapping hazardous areas}

The locations of hazardous areas were initially collected through focus group discussions with the fishermen and their Panglima Laot, with 16 captains reporting where they had recently damaged their nets. Based on this the Panglima Laot collectively decided, with captains and boat owners in agreement, that purse-seine fishing was to be prohibited in these areas (c. 30,00o ha) and that only smaller boats using handlines would be allowed to fish there. Four main fishing zones were identified to the west of Aceh (Fig. 2). Zone 2 was highlighted as the most dangerous fishing area because of the strong currents and abundance of underwater obstructions. The restriction was effective and the number of boats damaging their nets was reduced to only one occurrence during the course of the project, as opposed to at least 16 reported incidents since the 2004 tsunami.

Data collected throughout the project were periodically synthesized and the results communicated to the fishermen in the form of maps. From this it was found that the boat captains quickly gained knowledge of the hazardous areas that should be avoided. In July 2008 Acehnese purse-seine boats deployed their nets 143 times, 56 times to the west of
Aceh and 87 times to the east. In December 2008 boats deployed their nets a total of 124 times, 113 to the west of Aceh and 11 times to the east. The shift in fishing pressure from the east during July to the west in December is consistent with the seasonal high winds and large waves that occur off the west coast of Sumatra between late May and early August. In July, before the restriction against purseseine fishing had been implemented, when boats deployed their nets $26.8 \%(n=15)$ were within the area that would be later identified as Zone 2. In December, after the restriction had been issued, nets were deployed only four (3.5\%) times in the Zone 2 area.

\section{Mapping seamounts}

In total three new seamounts, three undersea canyons and 18 coral reefs were mapped. These seamounts, canyons and coral reefs previously did not appear on any of the published navigational charts (NOAA, British Admiralty and Bakosurtanal), or in the global list of seamounts (Yesson et al., 2011) or coral databases (Tupper et al., 2009). The largest of these seamounts is located $120 \mathrm{~km}$ off the west coast of Sumatra $\left(4^{\circ} \mathrm{O} 2.331 \mathrm{~N}, 94^{\circ} 41.380 \mathrm{E}\right)$ and is known locally as Melati (meaning jasmine).

According to existing charts and data collected from the fishermen's GPS/sounders, Melati rises from a depth of $1,800 \mathrm{~m}$ to within $8 \mathrm{~m}$ of the surface. Another peak, which rises to a depth of $50 \mathrm{~m}$, was found $6 \mathrm{~km}$ west-north-west $\left(4^{\circ} 03.819 \mathrm{~N}, 94^{\circ} 38.657 \mathrm{E}\right)$ of Melati and was dubbed 'Melati's little sister'. The top of both peaks were profiled using 12,600 data points collected by the fishermen. This information was presented first to the Indonesian Minster of Fisheries and subsequently to the Indonesian President during his February 2009 visit to Aceh. To provide protection for the 


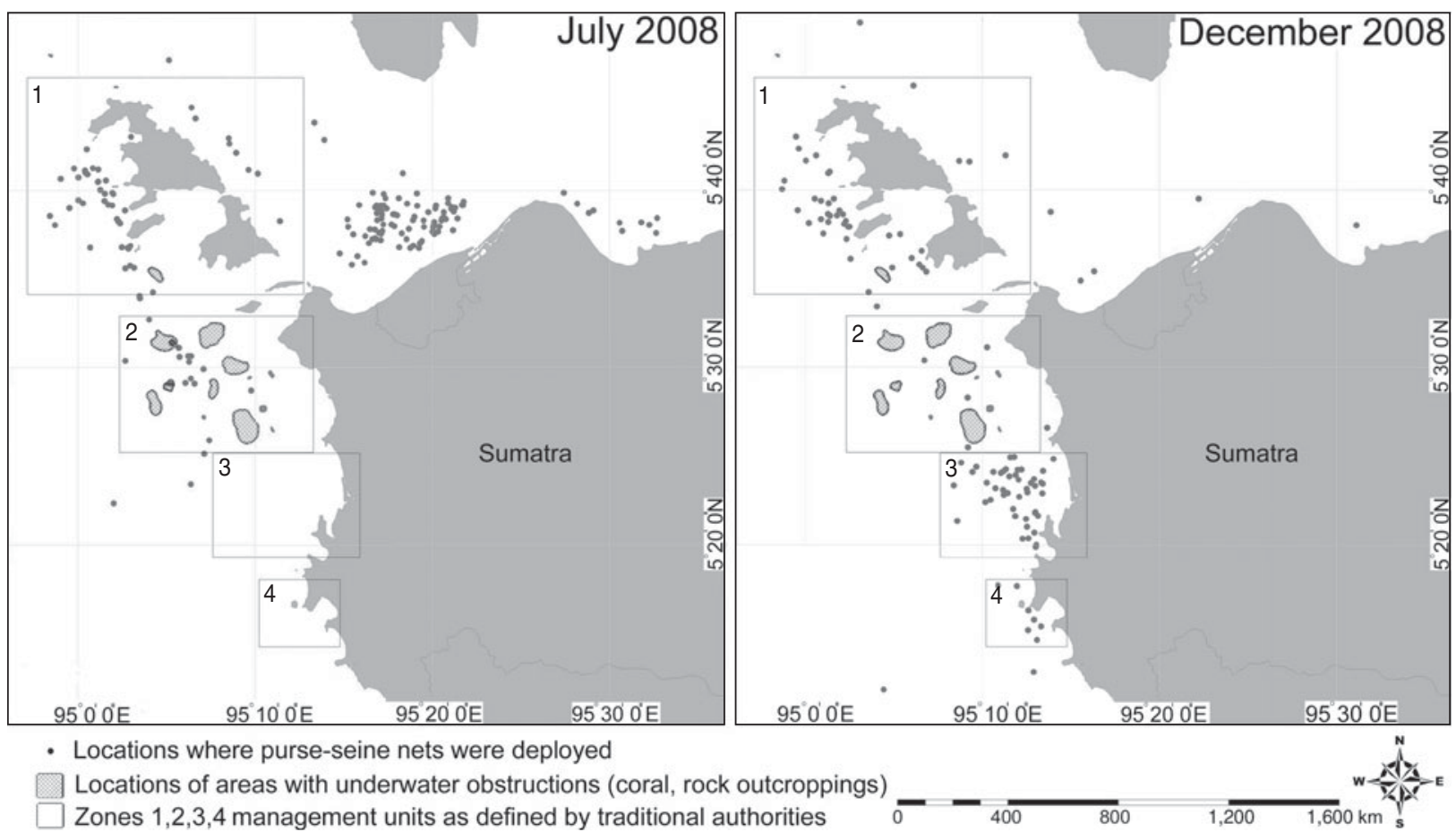

FIg. 2 Purse-seine fishing zones (1-4, see text for details) and coral areas west of Aceh in July and December 2008.

seamount the President issued an order that expanded Aceh's provincial boundary by $1,316,200$ ha so that both seamounts would be under the jurisdiction and protection of the marine police.

\section{Discussion}

This project demonstrated that in a comparatively short time-frame the fishermen of the Panglima Laot had the capacity to collect the necessary data to produce a nearshore map of sufficient scale and resolution to identify fishing resources and underwater hazards. The local fishermen's association leaders demonstrated that they have the necessary influence as well as ruling authority within the fishing community to collect the type of data needed to support the development and implementation of management plans. We found that by collecting the bathymetric data, producing the maps, and feeding back the information to the fishermen, the fishermen could stay out of certain dangerous areas and, consequently, dramatically reduce the frequency with which they ripped their nets and damaged the coral reefs. We also found that the traditional fishers possess unique knowledge of their waters and can work effectively with government authorities to protect even those resources far offshore.

\section{Community-based marine conservation}

There is a large body of literature citing the effectiveness and advantages of building co-management partnerships between government and traditional authorities to manage nearshore fisheries (Ruddle \& Johannes, 1985; Bailey \& Zerner, 1992; Ruddle et al., 1992; Pomeroy et al., 2004). Through the Aceh project's strong focus on creating networks and building partnerships, the marine VHF radios provided to 134 Panglima Laot and marine police was found to increase their communication and cooperation with each other on a wide range of activities, such as responding to distress signals and participating in programmes to combat the illegal fishing activities of international vessels.

The Panglima Laot demonstrated they have the ability to coordinate the gathering of requisite data for supporting the development of an inshore fisheries management plan, with all participating captains routinely providing GPS data from their boats. Furthermore, the Panglima Laot demonstrated they have the ability both to develop and enforce marine policies, as found with the translation of the map of hazardous areas into a prohibited zone for certain types of fishing. In turn this led to reduced net damage and overcame a key livelihood and conservation issue.

\section{Seamount conservation}

The community-based mapping identified several critically important, yet hitherto undocumented, seamounts. This forms part of a growing body of information that has recognized these marine ecosystems as hotspots of pelagic biodiversity (Etnoyer et al., 2010) and prioritized their 
protection (UN, 2011). Seamounts are highly productive environments that can serve as habitats for important commercial fish species, including migratory pelagic species such as yellow-fin tuna Thunnus albacares (Morato et al., 2010). Scientific knowledge of seamount locations, ecological functions and fish communities remains limited but local knowledge may help to address this. The mapping of the three seamounts demonstrated how the Panglima Laot could influence national policy because their discoveries, although long-known to them, led to an expansion of Aceh's provincial territory.

\section{Customary-based marine resource management}

The 400 year-old institution of the Panglima Laot has survived Dutch colonization, the Japanese occupation during World War II, the Indonesian government's attempt to centralize fisheries management (statute No. 5 of 1979), and the Indonesian government's efforts to decentralize authority back to the district level in 1999 (Act No. 22, 1999). It has evolved with modernization, with boats switching from sail power to motor power, using electric lights at night to attract fish instead of kerosene lanterns, and carrying ice on board to maintain the quality of fish caught.

The case of the Panglima Laot managing natural resources in Indonesia is not unusual, and there are similar authorities in other parts of the archipelago: the Sasi Laut in Maluku (Novaczek et al., 2001), Awig-awig in Lombok Utara (Satria et al., 2006), Lebak Lubung in South Sumatra (Pahlevi, 1998), Maawu Dabau (Basuki, 1996), Ikan Larangan and Ikan Diniatkan in West Sumatra (Pahlevi, 1998), Tara Bandu in Timor Leste (Sandlund et al., 2001), Lubuk Larangan in the Mentawais and Central Kalimantan (Wahyono, 1992), Punggawa-sawi (Pelras, 2000) and Mane'e in Sulawesi (Cinner et al., 2005), Panglima Menteng in Selayar (Lampe et al., 1997) and Sasi Lola in the Kei Islands (Thorburn, 2000).

Given the current situation of fisheries in the western hemisphere, where many of the fish stocks are overexploited or in decline (Pauly et al., 2002), it is perhaps counterintuitive for fisheries managers to consider that an important step in achieving larger conservation outcomes is to build the capacity of traditional fishermen to communicate and cooperate across a larger scale. Many of the problems in Indonesian fisheries are not, however, with the local community overexploiting their waters but rather with more recent open-access systems in which outsiders can legally fish or illegally 'bomb' an area, and then move on (Pet-Soede \& Erdmann, 1998). At a time when Indonesia is seeking to decentralize management, these networks of traditional fishermen offer a framework for fisheries management that seeks to build communication and cooperation across large areas.

\section{Acknowledgements}

We would like to thank the Panglima Laot, Asian Development Bank, BRR, the Aceh Marine and Fisheries Agency, Richard Kidd, Richard Coutts, Michael Phillips, Yakob Ishadamy, the Aceh Geospatial Data Centre, and the staff and students of the Department of Marine Economics at Syiah Kuala University.

\section{References}

Arie, H. \& Syahbudin, B. (2009) Breakthrough: Thousands of Paths toward Resolution, Volume 3 of BRR Book Series. Badan Rehabilitasi \& Rekonstruksi, Executing Agency of Rehabilitation and Reconstruction for Aceh and Nias, Banda Aceh, NAD, Indonesia.

Bailey, C. \& Zerner, C. (1992) Community-based fisheries management institutions in Indonesia. Marine Anthropological Studies, 5, 1-17.

Basuki, R. (1996) Maawu Dabau Bakuok (MDB): A Traditional System of Management for Fisheries in Bakuok Lake, Kampar Community, Riau Province. Jakarta, Indonesia.

Cinner, J., Marnane, M.J., McClanahan, T.R. \& Almany, G.R. (2005) Periodic closures as adaptive coral reef management in the Indo-Pacific. Ecology and Society, 11, 31.

Clifton, J. (2009) Science, funding and participation: key issues for marine protected area networks and the Coral Triangle Initiative. Environmental Conservation, 36, 91-96.

Etnoyer, P.J., Wood, J. \& Shirley, T.C. (2010) How large is the seamount biome? Oceanography, 23, 206-209.

Govan, H. (2009) Status and Potential of Locally-managed Marine Areas in the South Pacific: Meeting Nature Conservation and Sustainable Livelihood Targets through Widespread Implementation of LMMAs. Secretariat of the Pacific Regional Environment Programme/WWF/WorldFish-Reefbase/CRISP, Suva, Fiji.

Lampe, M., Salman, D., \& Ansar, A. (1996/1997) Analysis of Social Studies, South Sulawesi Province COREMAP. Research Reports. Universitas Hasanuddin-PPT-LIPI, Jakarta, Indonesia.

Morato, T., Hoyle, S.D., Allain, V. \& Nicol, S.J. (2010) Seamounts are hotspots of pelagic biodiversity in the open ocean. Proceedings of the National Academy of Sciences of the USA, 107, 9707-9711.

Novaczek, I., Harkes, I.H.T., Sopacua, J. \& Tatuhey, M.D.D. (2001) An Institutional Analysis of Sasi Laut in Maluku, Indonesia. ICLARM, Penang, Indonesia.

Nurasa, T., Naamin, N. \& Basuki, R. (1987) The Role of Panglima Laot "Sea Commander" System in Coastal Fisheries Management in Aceh, Indonesia. Twenty-Second IPFC Fisheries Symposium, Darwin, Australia.

PAhlevi, R.S. (1998) Ikan Diniatkan and Ikan Larangan: Areas of Traditional Fish Cultivation in the Districts of Pasaman and Padang Pariaman, West Sumatra Province. FAO, Chennai, India.

Pauly, D., Christensen, V., Guénette, S., Pitcher, T.J., Sumaila, U.R., Walters, C.J. et al. (2002) Towards sustainability in world fisheries. Nature, 418, 689-695.

Pelras, C. (2000) Patron-client ties among the Bugis and Makassarese of South Sulawesi. Bijdragen tot de Taal-, Land-en Volkenkunde, 156, 393-432.

Pet-Soede, C. \& Erdmann, M.V.E. (1998) Blast fishing in SW Sulawesi, Indonesia. NAGA, The ICLARM Quarterly, 2, 4-9.

Pomeroy, R.S., Parks, J.E. \& WAtson, L.M. (2004) How is your MPA doing? A Guidebook for Natural and Social Indicators for Evaluating Marine Protected Area Management Effectiveness. IUCN, Gland, Switzerland, and Cambridge, UK. 
Ruddle, K., Hviding, E. \& Johannes, R.E. (1992) Marine resources management in the context of customary tenure. Marine Resource Economics, 7, 249-273.

Ruddle, K. \& Johannes, R.E. (eds) (1985) The Traditional Knowledge and Management of Coastal Systems in Asia and the Pacific. UNESCO-ROSTSEA, Jakarta, Indonesia.

Ruddle, K. \& Johannes, R.E. (eds) (1990) Traditional Marine Resource Management in the Pacific Basin: An Anthology. UNESCO-ROSTSEA, Jakarta, Indonesia.

Sandlund, O.T., Bryceson, I., De Carvalho, D., Rio, N., Da Silva, J. \& Silva, M.I. (2001) Assessing Environmental Needs and Priorities in East Timor: Issues and Priorities. UNOPS report.

SATria, A., MATSUDA, Y. \& SANO, M. (2006) Questioning community based coral reef management systems: case study of awig-awig in Gili Indah, Indonesia. Environment, Development and Sustainability, 8, 99-118.

Thorburn, C. (2000) Sasi Lola in the Kei Islands, Indonesia: an endangered marine resource management tradition. World Development, 28, 1461-1480.

Tupper, M., Tan, M.K., Tan, S.L., Radius, M.J. \& Abdullah, S. (2009) ReefBase: A Global Information System on Coral Reefs. Http://www.reefbase.org [accessed 15 June 2009].

UN (2011) Oceans and the Law of the Sea. Report of the SecretaryGeneral, Session of the General Assembly, 66th Session, UN.

Wahyono, Untung, Chong, K.C., Suseno \& PAhlevi, R. (1992) Traditional community-based fisheries management practices in Indonesia. Seminar paper FAO/Japan Expert Consultation on the Development of Community-based Coastal Fisheries

Management Systems for Asia and the Pacific, 8-12 June 1992, Kobe, Japan.

Yesson, C., Clark, M.R., Taylor, M. \& Rogers, A.D. (2011) The global distribution of seamounts based on 30-second bathymetry data. Deep-Sea Research Part I-Oceanographic Research Papers, 58, 442-453.

\section{Biographical sketches}

CRISPEN WILSON has served as a project manager for the Sumatran Tiger Project and worked for the international zoo community. He has worked across a number of international conservation NGO networks (Conservation International, IUCN, Wetlands International, BirdLife International, TRAFFIC International and UN Environment Programme - World Conservation Monitoring Centre), helping those organizations share data with each other and within their various programmes. After moving to Aceh in 2007 he worked with the traditional fishing leaders to implement communitybased conservation strategies. He is currently in Timor Leste working with traditional fisher groups. MATTHEW LIN KIE has researched tiger conservation in Sumatra, a theme he continues by researching the impact of deforestation and poaching on large-bodied mammals across South-East Asia. He is a member of the IUCN/Species Survival Commission Tapir Specialist Group. 